Wales and Cumberland felspathic ashes being metamorphosed into felstone-like rocks.

Mr. Ward had always a strong bent towards educational work, and lectures of his first given to a school audience, and afterwards before the Keswick Literary Socicty, were expanded and publishcd as text-books ("Elcmentary Natural Philosophy" and "Elementary Geology," 1872). Like the late Canon Kingsley with the Chester Society of Natural Science, Mr. Ward exerted an immense influence in attracting people to the pursuit of natural science, and in breaking donn those trammels which prevent people of different ranks meeting for a common useful object; and not only increased the number of members of the Keswick Society and put its museam in scientific order, enriching it with his own collections, but united the society with the other societies of the county, and formed them into the Cumberland Association -a society publishing a useful journal. In $187 \mathrm{~S}$ he left the Geological Survey and entered the Church, holding successively two cures under the Bishop of Carlisle : the first, a curacy at Keswick; the second, the vicarage of Rydal. Thus in the shadow of Wordsworth's home, surrounded by the mountains he loved so well, he closed his useful, respected, and sadly too short life,

C. E. R.

\section{THE INSTITUTION OF MECHANICAL ENGINEERS}

$A \mathrm{~T}$ the recent meeting of the Institution of Mechanical A Engineers four papers were read on subjects of practical interest to engineers and men of science, viz., on Electric Lighting, by Dr. John Hopkinson, F.R.S. Remarks on Chernoff's papers on Steel, by Mr. W. Anderson of Frith. On Permanent Way for Street Tramways, with special reference to Steam Traction, by Mr. J. D. Larsen ; and on Water Pressure Engines for mining purposes, by Mr. H. Davey of Leeds.

Dr. Hopkinson's paper is divided into three principal parts. The first is a continuation of a paper read by the author in April, 1879, in which he exhibited by means of a curve the interconnection between the current passing through a dynamo-electric machine, the speed of revolution, and the electromotive force. Since the date of the authors earlicr paper other elec. tricians have made expcriments in the same direction; notably Auerbach and Meyer in Germany, and Dr. Siemens, F.R.S., in this country. The results arrived at by these experiments are now given in a similar form to that adopted by the author for illustrating his own experiences.

The second part of the paper deals with the brightness of the electric arc. It is common to speak of the brightness of an electric light in terms of so many candles. The colour of the electric light is how ever different to that of a candle. Henco "the statement without qualification, that a certain electric lamp and machine give a light of a certain number of camdles" "is wanting in definite meaning." "Captain Abney (Proceedings of the Royal Society, March 1878) has given the results of the measurements of the red, blue, and actinic light of electric arcs in terms of the red, bluc, and actinic light of a standard candle." It has also been ascertained that the electric light under certain circumstances gives very different intensitics of brightness in different directions. These two facts, together with ccrtain practical difficulties, have rendered the measurement of the light emitted by the electric arc somewhat difficult. In the second part of his paper Dr. Hopkinson describes the methods which he has adopted for overcoming these difficulties.

In the third section the author considers the efficiency of the electric arc, and concludes by giving a rule for the "measurement of the efficiency of any systen of electric lighting in which the electric arc is used, the arc being neither exceptionally long nor exceptionally short."

Mr. Anderson's remarks on Chernoft's papers on Steel are chiefly interesting as tending to direct attention to an almost unknown series of papers by a distinguished Russian metallurgist. Few men have had better opportunities for becoming acquainted with the nature of steel than M. Chernoff. He has been for some years assist ant manager of the cclebrated Abouchoff Steel Works, close to Sit. Petersburg. At these works five different processes of manufacturing steel, viz., the old crucible, the Siemens crucible, the Bessemer, the Siemens-Martin, and the Whitworth fluid compressed steel systems, may all be seen in operation. Visitors to the Vienna Exhibition in 1873 will remember the splendid specimens of artillery, including a breech-loading forty ton gun, which were turned out by this factory. The establishment is provided with an admirable laboratory, with one of Kirkaldy's testing machines, and with every appliance necessary for investigating the nature and properties of the metal. Under these circumstances any contribution to our knowledge of steel coming from the pen of $M$. Chernoff would prabably well deserve the attention of English metallurgists. The first of the papers referred to was published in 1868 , but was not translated into English till $x 876$. It deals with the chemical composition of steel, the effects of introducing extraneous subjects into its composition, and the effect upon its properties and molecular structure of heating the metal up to various temperatrues as high as the melting point, and then cooling it again from the melting point.

In $1876 \mathrm{M}$. Chernoff published a paper on the Bessemer Process, "which gives a number of interesting annlyses made at the Abouchoff works and elsewhere, and institurtes a comparison as to the dimensions of apparatus, quantity of air required, and other details, in different countfies and for various qualities of iron."

In 1878 he produced a paper on the Structure of CastSteel Ingots, which deals with the nature and origin of the defects to be met with in ingots, and the proper method of obviating them. This paper also goes into the very important question of whether steel-castings do or do not require subsequent treatment under the hammer, and the author gives tables of experiments to show that by proper annealing steel-castings can be rendered "fully as tough, tenacious, and ductile as the forged metal."

$\mathrm{Mr}$. Anderson has done good service by translating these papers for the berefit of English readers. He notices at the beginning of his own paper that the Russian language is so little understood that it is only by accident that the labours of many very distinguished Russians became known in Western Europe. We commend this nemark to the attention of the editorial committee of the Institution of Civil Engineers The Transactions of the Institution beenfit some time been remarkable for the admirble series of abstracts of papers Institution faroiga periodicals. No English committee of the mplain that the scientific publications of other countries are inaccessible to him, therefore it seems the greater pity that any little difficulty about the language showid cause the labours of Russian savants to have been overlooked.

The latter portion of Mr. Anderson's paper hasmosting to do with M. Chernoff. It deals principally utith the effect which occluded gases seem to play in the hardening and tempering of steel, and also considers the molecular changes, and the variations in the specific gravity of steel brought about by tempering. On this point we should like to draw the author's attention to a most interesting series of experiments by Dr. Schott, a German, on the effect of tempering glass in oil ; a résume of which is to be found in the foreign abstracts of the last volume of "Transactions of the Institution of Civil Engineers." 
A study of this paper may perhaps throw some light on the corresponding problems in the manufacture of steel.

Mr. Larsen's paper on the Permanent Way of Street Tramways is an eminently technical production, and deals with the forms of rails and nature of sleepers and crossties necessary to secure not only a good and permanent road for the present system of traffic, but also one which can be readily adapted to steam traction, whenever sufficiently perfect steam traction shall have been introduced to take the place of horses.

Tramways have not hitherto succeeded in earning the sympathy of those sections of the public who travel in cabs and carriages. Owing to the peculiar kind of rail used, and the imperfect manner in which the tramway proper has been combined with the paving of the ordinary road, street vehicles have experienced a very nasty and injurious species of wrench and jolt, when crossing the rails, which, besides being very uncomfortable to the occupier of the carriage, is also extremely injurious to his wheels. In addition to this drawback the earlier tramways were laid on a very bad system. They rapidly got out of order. Owing to the spikes which fastened down the rails having been driven down from the upper side, the rain used to percolate downwards between the spike and its holding in the sleeper, so that the wood of the latter became soft, and spike and rail consequently worked loose. In fact, in the older tramways it was the exception to find a rail in good order. The difficulty of setting the paving stones properly in the neighbourhood of the longitudinal timber sleepers was so great that the surface of the roadway almost invariably settled down thereabouts into a continuous longitudinal depression, which in wet weather became a stagnant ditch, not only unsightly, but extremely inconvenient to foot passengers and ordinary traffic. Mr. Larsen in his paper describes the various inventions and contrivances brought out by himself and other engineers for the purpose of remedying these drawbacks, and of making the permanent way so secure and rigid that it can be used at any time for steam traction.

The author does not refer to one of the greatest novelties in permanent-way construction, viz., the glass sleepers brought out by Mr. Lindsay Buckill and Mr. W. Siemens of Dresden. These sleepers have been laid down for some time past on a section of one of the Metropolitan tramway lines, and appear to have answered their purpose most successfully. The fact that glass, proverbially the most brittle of substances, could be used for such a purpose, might strike most people with surprise ; but readers of Dr. Schott's paper, referred to above, will have learned that by suitable tempering glass may be made, mass for mass, stronger than steel, and practically unbreakable. We understand that the success attained in the construction of glass sleepers has recently been so great that it is now proposed to make broad longitudinal sleepers with a groove in the upper surface which shall combine in themselves the functions of rail and sleeper, and do away with the necessity for separate iron rails with their fastenings, joints, and other concomitant complications.

Mr. Henry Davey's paper on water-pressure engines for mining purposes would scarcely be understood without reference to the diagrams and illustrations made use of by the author. Its character is moreover so essentially technical as to render it unsuited for reproduction in this journal.

\section{NOTES}

We take the following from the Times:-The following are the names of the fifteen candidates for the Fellowship of the Royal Society selected by the Council and recommended for election (Thursday, June 3 , is the day appointed for the election) :-Dr. Clifford Allbutt, Prof. J. Attfield, Mr. H. E. Blan- ford, the Rev. W. H. Dallinger, Mr. Thiselton Dyer, Lieut.Col. Godwin-Austen, the Bishop of Limerick, Prof. D. E. Hughes, Mr. H. M. Jeffery, Prof. F. M'Coy, Mr. J. F. Moulton, Prof. C. Niven, Dr. J. Rae, Prof. J. E. Reynolds, Dr. W. A. Tilden.

Prof. BAyley BAlfour returned last week from Socotra, with considerable botanical and zoological collections made during his necessarily very brief visit. $\mathrm{He}$ obtained dried specimens of 500 species of flowering plants, and four cases of living specimens, besides a large plant of the Dracana, which yields the dragon's blood of Socotra, and which, till recently, was quite unknown to science. $\mathrm{He}$ attempted to convey with him through Italy a small case of succulent plants of special interest, but it was stopped at the Custom House at Brindisi, and unless it finds its way to England by the sea route, its contents are of course lost.

WE regret to learn of the death, after a short illness, of $\mathrm{Mr}$. W. H. Holloway, F.G.S., of the Geological Survey of England and Wales.

The Portuguese Naturalist Anchietta has recently sent from Africa 2,000 specimens of birds and 1,000 reptiles, fishes, insects, and other animals, besides numerous specimens of plants and rare minerals. They are intended for the Polytechnic Museum of Lisbon.

THE Newcastle Chronicle announces the death, at Gosport, of Mr. Thomas Atthey, a naturalist of considerable reputation. Although living in comparative obscurity and quiet, he was well known and highly esteemed in learned circles for his researches in and contributions to that branch of science to which he was so much attached, his position being very much akin to that of Thomas Edwards.

The Irish Farmers' G.xzette understands that Prof. Baldwin is about to retire on a well-earned pension from the appointment he has so ably filled for many years as Superintendent of the Agricultural Department of the National Board, Dublin.

THE Dharwar correspondent of the Bombay Gazette gives a graphic account of a thunderstorm which occurred on March 24 last, and was accompanied by a fall of some very heavy hailstones. "The storm," the correspondent states, " was ushered in by the fall of some extremely heavy hail, several of the largest stones, which were spherical in shape, measuring no less than nine or ten inches in circumference. He did not himself see these?monster hailstones, but he vouches for the accuracy of this statement. He picked up several hailstones, however, himself, which were the size of Tangier oranges. Accompanying this storm of hail were thunder and lightning, both on a grand scale, the latter at times being very vivid. After the hail came a heavy downpour of rain, and the whole affair was over by about $8 \mathrm{p.m}$. One piece of ice was picked up about five inches long and pointed at one end." The correspondent who sends us this writes : "It is a pity that these remarkable hailstones were not more closely examined and measured. Of course there are cases on record of still larger stones having fallen, especially in tropical countries."

THE programme of the annual meeting of the Iron and Steel Institute, to be held on May 5, 6, and 7, has just been issued. The Bessemer medal for 1880 is to be presented to Sir Joseph Whitworth, and among the papers to be read and discussed are the following:- "On Hardening Steel, its Causes and Effects;" "Physical Changes occurring in Iron and Steel at High Temperatures;" "Manufacture of Bessemer Steel and Ingot Iron from Phosphoric Pig;" "Dephosphorisation of Iron at the Hördeworks, Germany;" "Reactions in the Open-hearth Process;" "Improved Method of Utilising By-products in the 